\title{
What causes depression in adults?
}

\begin{abstract}
The problem of depression in adolescents is discussed increasingly more often. A lot of researchers devote their careers to investigating this subject. The issue becomes vital, since the number of young people with depressive symptoms is constantly on the rise. The diagnosis can be difficult, as many a time the changes so typical for the puberty period appear. They include mood swings, explosiveness, propulsion disorders, puissance, insomnia, concentration problems etc. These might be the first symptoms of depression as well. It is impossible to point to one cause of depression because it is a disease conditioned by many different factors, ranging from independent factors like genetic, biological, hormonal, through the influence of the family or the environment influence and socio-cultural components.

Early depression symptoms, long time exposure to stress, challenges or adversities - things every young person has to deal with - are a breeding ground for risky behaviors among adolescents. Teens are more likely to reach for different kinds of stimulants like alcohol, cigarettes or drugs etc. It has also been proven that anti-health behaviors may cause depression in the future.
\end{abstract}

Keywords: adolescent depression, risk factors, adolescents, behavior, anti-health.

DOI: $10.1515 /$ pjph-2015-0037

\section{INTRODUCTION}

Depression in adolescents is a particular example of an emotional and behavioral disorder, typical for the puberty period. It is associated with changes in the endocrine system that normally happen during that age. Those changes are due to the development of new cognitive functions and taking new roles in society. During that period, a child achieves an emotional autonomy and formal independence from their family [1]. Every young person considers that period of life as extremely difficult. They need a greater understanding from their family and the environment, as well as more attention to unusual behavior.

Not all young people are equally exposed to depression. The results confirm the participation of many factors that lead to depressive disorders and affect the progression of the disease. The studies also show gender differences in the prevalence of depression. In children, the prevalence of depression is equal in both genders. Some significant differences appear along with maturation (depression symptoms are more frequent in girls), clearly these differences are revealed between 13 and 15 years of age, and reach its peak at the age of 15-18 years, so this group is at a higher risk to suffer from depression especially in the population of girls [2].

There is no single source of depression. It is a multifactorial disease, which means it might be caused by a range of factors, including genetic, hormonal, biological, as well as the impact of family and other socio-cultural factors [3].
How mothers negative emotions affect the fetus during pregnancy?

Since early pregnancy, the mothers' emotions significantly affect the formation of synapses and the neurotransmitters secreted by the mother modify the development of a child's brain. Under the influence of stress during pregnancy, the mother's body may release stress hormones the presence of which can affect the whole life of the unborn child. Depending on how strong the negative emotions are and how long they last, it leads to a modification of synapses in the fetus' brain and exerts a destructive effect on neurons and glial cells [4].

Severe chronic stress by inhibiting the neurogenesis and by contributing the atrophy of neurons, causes many anatomical and pathophysiological changes: reduces the number of neurons. It also deteriorates the communication between neurons, decreases neuroplasticity, entailing depressive symptoms [5].

With use of fMRI (functional Magnetic Resonance Imaging), besides significant destructive changes in the brain, it was also found that children of women who have experienced severe stress and negative emotions both during pregnancy and after birth, often also have enlarged amygdaloid nucleuses (brain structures that regulating emotional reactions and responsible for feelings of anxiety, panic and aggression). The stronger the maternal stress is, the greater the volume of amygdaloid nucleus in the child [6]. 
The infants whose mothers suffered from depression also show a decreased activity of EEG (electroencephalography) of the left hemisphere, mainly of the left frontal lobe. The stronger the negative emotions of the mother are, the lower is the EEG activity in the child's brain [7].

It is also shown that epigenetic changes in the form of $\mathrm{H} 3 \mathrm{~K} 14$ hyperacetylation in the promoter of the gene BDNF (brain-derived neurotrophic factor) in the prefrontal cortex are responsible for emotional memory. This means that the experience of the fetal period may disappear in emotional memory for many years, sometimes for the rest of one's life and may be the cause of unexplained fears [8].

\section{Genetic causes}

Scientific research proves that the mother's depression and her anxiety during pregnancy can be inherited and can cause anxiety and depressive disorders in the newborns [9].

It is estimated that the people, whose first-degree relatives suffer from depression are 1.5 to 3 times more likely to develop depression. According to some studies, depression can be associated with genes occupying a fixed position on chromosome 8, 15 and 17 [10].

The scientists also conducted studies of the nervous tissue in deceased people who had suffered from depression before death. The results have shown that depression contributes to the formation of a gene MKP-1 (mitogen-activated protein kinase phosphatase-1), which was 2 times more active in patients than in the healthy group. An increased expression of MKP-1 located in the hippocampus, as a result of stress, initiated depressive behaviors. On the other hand, chronic antidepressant treatment with normalized the expression of MKP-1. Using these results, it can be concluded that stress remains one the main factors causing depression. It increases the expression of the MPK-1 gene [11].

Recent research published in the Journal of Inherited Metabolic Disease, conducted among children with congenital disorders of glycosylation (CDG) confirm a higher incidence of social-emotional disorders, such as symptoms of depression, social withdrawal and somatic disorders in children diagnosed with CDG, compared to healthy children, children with mitochondrial disorders and other types of metabolic diseases. In more than two thirds of the children with CDG it was observed a variation in the abnormal behavior identification test -The Child Behavior Checklist (CBCL). The authors emphasize the importance of psychological screening tests among patients with disorders of glycosylation, as a group of an increased risk of developing socioemotional disorders, including depressive behavior [12].

Some studies suggest that psychosocial factors seem to predispose to the disease only in conjunction with the inherited genetic predisposition to depression, especially the interaction of polymorphisms of 5-HTT (5-hydroxytryptamine transporter), COMT (catechol-O-metyltransferase), MAO-A (monoamine oxidase A), CRHR1 (corticotropin releasing hormone receptor 1), and environmental factors. Further studies looking at the interactions of these genes with stressful factors should be conducted [13].

\section{Biological causes}

The biological reasons are associated with disorders at the level of the neurotransmission in brain including substances such as serotonin, norepinephrine, dopamine, gamma aminobutyric acid (GABA), cerebral nerve growth factor (BDNF - brain-derived neurotrophic factor) and others $[14,15]$.

It is assumed that the reduced production of these neurotransmitters can cause symptoms of depression, and may be responsible for the emergence of suicidal thoughts and actions.

Research studies carried out at the University of Pisa in Italy confirm that serotonin deficiency plays a significant role in the development of depression. It was also shown that kynurenine seriously affects the central nervous system by increasing the expression of the "tryptophan-kynurenine" and in this way determines the serotonin deficiency. The layout "tryptophan-kynurenine" also affects the formation of anxiety disorders, psychotic symptoms and depressive disorders. Kynurenine pathway of tryptophan metabolism leads to the formation of multiple active metabolites, which act antagonistically relative to each other. At first, the amino acid is metabolized to formylkynurenine, which is converted to the kynurenine. Two enzymes are involved in this reaction: 2,3 tryptophan dihydrooxygenase [TDO], activated by stress hormones and indoleamine 2,3 dioxygenase [IDO], activated by pro-inflammatory cytokines. The increased expression of genes producing cytokines (IFN $\gamma, \mathrm{TNF}-\alpha$ ) may determine a genetic predisposition to the formation of depression (by activation the pathway of IDO), and environmental stimuli activate the TDO path at hormonal level. It is suggested that the system "tryptophan-kynurenine" may be one of the main sites of interaction between genetic and environmental factors involved in the pathophysiology of depression [16].

\section{Social factors and lifestyle}

This can include family problems, traumatic experiences, all kinds of stress, addiction, being overwhelmed with daily duties, insomnia, etc.

\section{Influence of family}

Here, it is both the relationships between parents themselves, as well as their relation with children. There might be conflicts, divorce, alcoholism in the family, including the mental health disorders and domestic violence of a sexual or moral nature. According to an article published by Journal of the American Academy of Child \& Adolescent Psychiatry in 2004, a family history of susceptibility to depression and the level of parental education has a significant impact on the occurrence of depressive symptoms among adolescents. They are at three-fold higher risk of developing depressive symptoms [17].

Some findings by Polish authors also confirm the role of pathogenic factors associated with the family system in the development of depressive symptoms among young people. It is emphasized, though, the development of depression is most likely the result of the interaction of genetic, cognitive, emotional, interpersonal factors and family environment [18]. 
There were some studies conducted in 1999 that looked at the relationship between depression among women and their potential childhood sexual abuse history. The results confirmed that sexual abuse in childhood is associated with the occurrence of depression in later life for both women and men. There is some evidence suggesting that early stressors result in distant as a dysfunction of the hypothalamic-pituitary-adrenal axis, which is also observed among patients with depression. Furthermore, this type of disorders finally leads to other, varying responses to stress stimuli in adulthood. Moreover, it seems that women are more susceptible to this kind of stress-induced hormonal disturbances which may be linked with a greater number of depression episodes among women. This study showed that sexual abuse in childhood is an important early factor that may predispose to depression later age by dysregulations in the hypothalamic-pituitary-adrenal axis [19].

Some Dutch studies investigating the relationship between childhood abuse and the onset of depression in later life, clearly indicate a strong relationship, even if first depressive symptoms are at a later age (over 60 years). The study was conducted among 378 people with symptoms of depression, and 132 individuals without depression, aged 60-93. The term "use" meant mental abuse, physical, sexual abuse and emotional neglect. Examples of 53\% among studied patients with depressive symptoms have confirmed the episode of abuse in childhood, as opposed to $16 \%$ of people without depression. The emergence of depression was mainly related to the physical abuse and the least on sexual harassment, but the incident of child abuse affects the depression, both in the early, middle and late ages. Later in life, the total number of chronic diseases among patients abused in childhood is expected to increase [20].

According to the hypothesis of Hammen (1991), people with depression and with tendency to develop depression are likely to experience negative life events caused by their own behavior. The results of American studies studies suggest that negative cognitive patterns, especially among patients with a history of childhood emotional abuse episode may trigger the occurrence of negative life events, and thus potentially may increase the risk of depression [21].

There is some further data elicited by University of Toulouse researchers through studies performed among the population of sub-Saharan Africa. These studies describe the relationship between trauma episodes in childhood and major depressive and personality disorders in adulthood. The studies involved 181 patients (90 with symptoms of depression, and 90 with no psychiatric history). People with depression reported more episodes of emotional, sexual and physical abuse and neglect in childhood. The results confirmed that the emotional and sexual abuse in childhood is associated with symptoms of depression and personality disorders in later age [22].

\section{The school environment}

An increasing level of stress associated with school, education, competition among the students, and the expectations bar set too high by teachers and parents is being observed. In 2005, a number of studies was conducted in Norway, where students aged 12-15 years were researched upon in order to establish the correlation between the influence of the school environment and depressive disorders.

The results confirmed the correlation between the occurrence of school stress, well-being in the classroom, relationships with teachers, the school grades and of symptoms of depression, especially among girls [23]. It was also proved that more than two times oftener depressive symptoms affect young people playing the role of the offender and as well the victim in the phenomenon of moral harassment at school [24].

\section{Sociocultural factors}

Factors such as education, religion, value systems, social conditions, behavioral patterns also play a significant role in the development of depression.

The importance of these factors is confirmed by studies conducted in South Africa and Mauritius, in an environment of low socio-economic standard in the group of girls aged between 14 and 17 years of age. These studies have confirmed the existence of self-destructive thoughts in almost $1 / 4$ of the respondents, and the attempt of self-harm respectively in $16.7 \%$ and $14.6 \%$ of girls. More than $30 \%$ of the studied had depressed mood and felt sad for over the past five years, while more than half of Mauritanian girls and 32.1\% of African girls were unable to cope with their problems, and a large part of them did not know where to turn for help [25].

\section{Other factors}

Changing the place of residence, school, as well as the sense of hopelessness and meaninglessness of life are also predisposing factors for developing depression. Also, this rings true for other issues related to sexuality, somatic disorders, trauma.

It has been proven that more than two-fold higher depressive symptoms affect young people implicated in bullying, both in the concept of the perpetrator and the victim. The consumption of psychoactive substances by adolescents seems to be also a significant problem [26].

Depressive disorders, the mental and emotional instability are associated with all sorts of attempts to escape from reality and the daily hardships, which contributes to the stress exponent, loss of energy, psychomotor slowing, changes in biological rhythms, appetite, immune, and use by the youth stimulants such as cigarettes, drugs, increasingly fashionable boosters and alcohol. The frequency of using these substances by adolescents is increasing with each passing year. Despite a great number of health-related programs and prevention, young people are not sufficiently aware of the dangers and they even do not realize how it can influence their future.

Recent research conducted in Taiwan among young people with varying degrees of depression, confirm that adolescence with severe depression more often benefit from stimulants such as cigarettes, alcohol, drugs or sedatives and hypnotics than those from the healthy group. Similar patterns are observed in young people with mild symptoms of depression, who comparing to the healthy population, more often reach for this type of drugs. There was impact of gender and age on the level of the disorder and the use of the substance [27]. 
The results of the studies conducted at the University of Washington among seven-years old children show that there is a relationship between antisocial behavior among girls and anxiety disorders among both sexes and the incidence of depression in adolescence. However, the early symptoms of depression among a group in early childhood do not necessarily cause the development of adolescent depression in the future [28].

The scientists from Canada, using some previous research show that alcohol consumption, even in small quantities, may increase the risk of occurrence the severe depression and suicidal tendencies [29].

Similar results were presented in 2012 by the Journal of Studies on Alcohol and Drugs. The authors confirmed that depression is a significant risk exponent of alcohol use in early age [30].

A nearing effect on the development of depression is attributed to smoking addiction. The study results presented in 2008 by the British Journal of Psychiatry confirm the effect of smoking on the development of depressive disorders in women environment. A higher incidence of depression was found among smoking women than among non-smokers [31].

According to data acquired by researchers from the University of Navarra in Spain, people addicted to smoking are $41 \%$ more likely to develop depressive disorders than nonsmokers. In addition, patients who stopped smoking and do not smoke cigarettes for more than 10 years, are at a lower risk of occurrence depressive symptoms than those who never smoked [32].

There are also studies dedicated to the impact of all kinds of chemicals, including medication and drugs, on the appearance of depressive disorders. The latest American results show that prenatal exposure to chemical substances (drugs/ narcotics) affects the adolescence and is characterized by disturbances in the emotional sphere, the emergence of symptoms of anxiety, depression in childhood, what may potentially increase the risk of violent behaviors among young contemporaries. The authors showed that young people who were prenatally exposed to toxic substances, more often are more likely to behave aggressively, be anxious or depressed than the group not exposed to these factors [33].

The lifestyle appears to be another problem. Due to the fact that more and more people live a sedentary life, they are more likely to experience mood swings, have low opinion of themselves and it deteriorates their already low self-esteem [34].

Behavioral changes, mood swings, anxiety, physical activity and appetite disorders, stress, drug or alcohol addiction decreased organism's immunity [35] - all of this is inseparably linked with depression. Furthermore, the risks described above also affect antihealthy behaviors, worsening the symptoms of depression. Young people with symptoms of depression, addicted to all type of drugs and involved in risky behaviors, are somehow caught in a "trap", from where is no escape without any professional help.

\section{REFERENCES}

1. Bomba J, Orwid M. Zaburzenia zdrowia psychicznego w okresie młodzieńczym. Postępowanie, profilaktyka, błędy w postępowaniu. Med Młodzieżowa; 2006. [http://www.kpdim.cm-uj.krakow.pl/1.pdf]

2. Hankin BL, Abramson LY, Moffitt TE, et al. Development of depression from preadolescence to young adulthood: emerging gender differences in a 10-year longitudinal study. J Abnorm Psychol. 1998;107(1):128-40.

3. Nemade R, Reiss N, Dombeck M. Biology of Depression-Neurotransmitters. Mental Help. [https://www.mentalhelp.net/articles/biology-ofdepression-neurotransmitters]

4. Jośko-Ochojska J. Lęk - nieodłączny towarzysz człowieka od poczęcia aż do śmierci. Katowice: Śląski Uniwersytet Medyczny w Katowicach; 2013.

5. Jośko-Ochojska J. Wpływ dramatycznych przeżyć i lęków matki ciężarnej na losy jej dziecka. Lęk - nieodłączny towarzysz człowieka od poczęcia aż do śmierci. Katowice: Śląski Uniwersytet Medyczny w Katowicach; 2013.

6. Lupien S, Parent S, Evans A, et al. Larger amygdala but no change in hippocampal volume in 10-year-old children exposed to maternal depressive symptomatology since birth. PNAS. 2011;108(34):14324-9.

7. Bruder G, Tenke C, Warner V, at al. Electroencephalographic measures of regional hemispheric activity in offspring at risk for depressive disorders. Biol Psychiatry. 2005;57:328-35.

8. Bredy T, Wu H, Crego C, et al. Histone modifications around individual BDNF gene promoters in prefrontal cortex are associated with extinction of conditioned fear. Learn Mem. 2007;14:268-76.

9. Weissman M, Pilowsky D, Wickramaratne P, et al. Remissions in maternal depression and child psychopathology: A STAR*D-child report. JAMA. 2006;295(12):1389-98.

10. Holmans P, Weissman M, Zubenko G, et al. Genetics of recurrent earlyonset major depression (GenRED): final genome scan report. Am J Psychiatry. 2007;164(2):248-58.

11. Duric V, Banasr M, Licznerski P, et al. A negative regulator of MAP kinase causes depressive behavior. Nat Med. 2010;16(11):1328-32.

12. Van de Loo K, van Dongen L, Mohamed M, et al. Socio-emotional problems in Children with CDG. JIMD Rep. 2013;11:139-48.

13. Wurtman R. Genes, stress and depression. Metab. 2005;54:16-9.

14. Masi G, Brovedani P. The hippocampus, neurotrophic factors and depression: possible implications for the pharmacotherapy of depression. CNS Drugs. 2011;1(25):913-31.

15. Hettema J, An S, Neale M, et al. Association between glutamic acid decarboxylase genes and anxiety disorders, major depression, and neuroticism. Mol Psychiatry. 2006;11(8):752-62.

16. Marazziti D, Baroni S, Picchetti M, et al. New developments on the serotonin hypothesis of depression: shunt of tryptophan. Riv Psichiatr. 2013;48(1):23-34.

17. Eley TC, Lian H, Plomin R, et al. Parental Familial Vulnerability, Family Environment, and Their Interactions as Predictors of Depressive Symptoms in Adolescents. J Am Acad Child Adolesc Psychiatry. 2004;43(3):298-306.

18. Greszta E. Family environment risk factors of depression in adolescence. Psychiatr Pol. 2006;40(4):719-30.

19. Weiss E, Longhurst J, Mazure C. Childhood sexual abuse as a risk factor for depression in women: psychosocial and neurobiological correlates Am J Psychiatry. 1999;156(6):816-28.

20. Comijs H, van Exel E, van der Mast R, et al. Childhood abuse in late-life depression. J Affect Disord. 2013;147(1-3):241-6.

21. Liu R, Choi J, Boland E, et al. Childhood abuse and stress generation: The mediational effect of depressogenic cognitive styles. Psychiatry Res. 2013;206(2-3):217-22.

22. Kounou K, Bui E, Dassa K, et al. Childhood trauma, personality disorders symptoms and current major depressive disorder in Togo (2012). Soc Psychiatry Psychiatr Epidemiol. 2013;48(7):1095-103.

23. Undheim. AM, Sund AM. School factors and the emergence of depressive symptoms among young Norwegian adolescents. Eur Child Adolesc Psychiatry. 2005;14(8):446-53.

24. Saluja G, Iachan R, Scheidt PC, et al. Prevalence of and risk factors for depressive symptoms among young adolescents. Arch Pediatr Adolesc Med. 2004;158(8):760-5.

25. Pillay A, Bundhoo H, Bhowon U. Depression-related distress in Mauritian and South African adolescent girls: an exploratory investigation. Psychol Rep. 2010;107(1):87-94. 
26. Saluja G, Iachan R, Scheidt PC, et al. Prevalence of and risk factors for depressive symptoms among young adolescents. Arch Pediatr Adolesc Med. 2004;158(8):760-5.

27. Wang $\mathrm{P}$, Lin $\mathrm{H}$, Yeh $\mathrm{H}$, et al. The relation of substance use with different levels of depressive symptoms and the moderating effect of sex and age in Taiwanese adolescents. Compr Psychiatry. 2012;53(7):1013-20.

28. Mazza J, Abbott R, Fleming C, et al. Anti-social behavior in girls predicts adolescent depression seven years later. The Journal of Early Adolescence. National Institute on Drug Abuse. University of Washington; 2009.

29. Goldstein B, Levitt A. Is current alcohol consumption associated with increased lifetime prevalence of major depression and suicidality? Results from a pilot community survey. Compr Psychiatry. 2006;47(5):330-3.

30. McCarty C, Wymbs B, King K, et al. Developmental Consistency in Associations Between Depressive Symptoms and Alcohol Use in Early Adolescence. J Stud Alcohol Drugs. 2012;73(3):444-53.

31. Pasco JA, Williams LJ, Jacka FN, et al. Tobacco smoking as a risk factor for major depressive disorder: population-based study. Br J Psychiatry. 2008;193(4):322-6.

32. Villegaz A, Martinez Gonzalez M, Garcia I. Smokers have a $41 \%$ higher risk of suffering depression, according to research from the University of Navarra. [http://www.sciencedaily.com/releases/2008/04/080424103225.htm]

33. Buckingham-Howes S, Oberlander S, Kim E, et al. Prenatal Drug Exposure and Peer Victimization in Early Adolescence: Testing Childhood Anxiety/Depression and Aggression as Possible Mediators. J Dev Behav Pediatr. 2012;33(5):416-22.

34. Hong, X, Li J, Xu F, et al. Physical activity inversely associated with the presence of depression among urban adolescents in regional China. BMC Public Health. 2009;9:148.

35. Wójciak P, Sobieska M, Kostrzewa A, Rybakowski P. Ocena aktywności wybranych elementów układu odpornościowego w depresji. Psychiatr Pol. 2007;XLI(5):637-49.

\section{Corresponding author}

Marta Bembnowska

20 Węgierska Str., 42-612 Tarnowskie Góry

tel. 504-243-112

E-mail: martulon@poczta.fm 